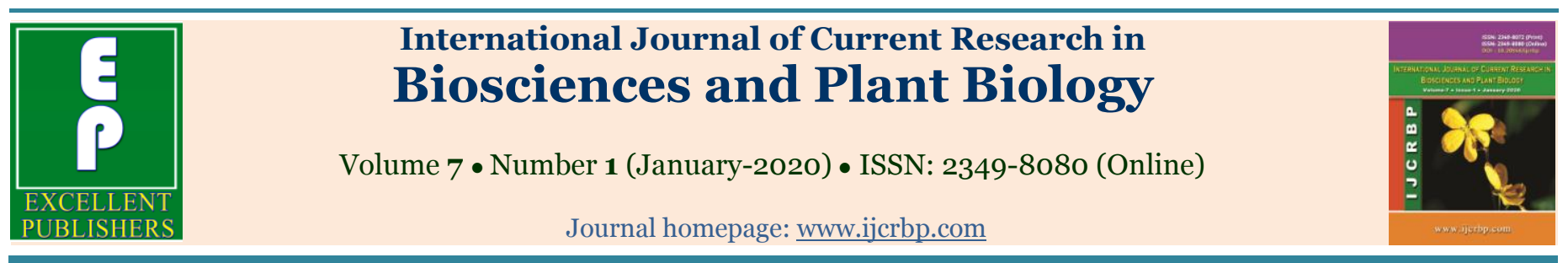

\title{
Effects of planting bed and mineral fertilization on the production and growth of Extra Sweet pineapple (Ananas comosus L.) aerial suckers in the locality of Bonoua, a town in south eastern Côte d'Ivoire
}

\author{
Kanga N'guessan Martial*, Cherif Mamadou, Sanogo Souleymane, Tuo Seydou, \\ Yao Kouadio Jacques Edouard , Kouassi N'dri Pacôme, Konan Kouakou Séraphin, \\ Bomisso Edson Lezin, Camara Brahima, Sorho Fatogoma, Dick Acka Emmanuel \\ and Koné Daouda
}

\author{
University Félix Houphouët Boigny, UFR (Faculty) of Biosciences, Laboratory of Plant Physiology, \\ 22 BP 582 Abidjan 22, Côte d'Ivoire \\ *Corresponding author; e-mail: nguessmarti@yahoo.fr
}

\begin{tabular}{|c|c|}
\hline le Info & ABSTRACT \\
\hline & \multirow{4}{*}{$\begin{array}{l}\text { The introduction of MD2 pineapple in the international fruit trade has helped to } \\
\text { drastically reduce exports from Côte d'Ivoire, which has long been the European market } \\
\text { leader with the smooth Cayenne variety. As a result, Ivorian producers must adopt } \\
\text { MD2cultivation which involves sucker availability. This study aimed at assessing the } \\
\text { effect of planting beds and manures on the growth and development of aerial suckers } \\
\text { produced after fruit harvesting. The planting beds studied included: film-covered ridges } \\
\text { (BAP), uncovered ridges (BSP) and flat soils (TP). The manures used included: F1: Urea } \\
+ \text { Potassium }+ \text { Trace elements (Boron }+ \text { Zinc), F2: Urea + Potassium + Nitrogen, } \\
\text { Phosphorus and Potassium compound (NPK) / Magnesium Monoxide + Trace elements } \\
\text { (Boron + Zinc), F3: Urea + Potassium and F4: Urea + Potassium / Nitrogen, } \\
\text { Phosphorus and Potassium compound (NPK) / Magnesium Monoxide. The design was } \\
\text { a split-plot. Planting bed was the main factor and manure was the secondary one. The } \\
\text { results obtained showed that on the BAP and BSP planting beds, sucker growth and } \\
\text { production were statistically identical and higher than those observed on TP. Moreover, } \\
\text { manure did not have a significant effect on sucker production and growth. The results } \\
\text { obtained make it possible to say that the BAP and BSP planting beds should be } \\
\text { recommended with one of the manures for a sustainable production of suckers. }\end{array}$} \\
\hline $\begin{array}{l}\text { Date oJ Publicanon: } \\
\text { o6 January } 2020\end{array}$ & \\
\hline Key & \\
\hline & \\
\hline
\end{tabular}

\section{Introduction}

Pineapple is a herbaceous Monocotyledon belonging to the Bromeliaceae family (Collins, 1960). The species includes varieties that are all grown for consumption. In Côte d'Ivoire, its cultivation started around 1940 with the smooth
Cayenne cultivar and became significant from 1970 (OCAB, 2000). For many years the country has been the main supplier of the European market in fresh pineapple (Charrier et al., 1997) with the smooth Cayenne. With this variety, it ranked first among African exporters, ahead of Ghana (35,000 t) and Cameroon (9,300 t) 
(Mangara, 2010). In the national economy, it contributes $1.6 \%$ to agricultural GDP and $0.6 \%$ to national GDP (Anonymous, 2015). The yield was 210,000 tons in 1999, and covered the European market with a rate of about $95 \%$. Since the 2000s, the cultivar (smooth Cayenne) produced in Côte d'Ivoire has faced unprecedented competition from the Extra-sweet or MD2 variety fruits (Paqui, 2007). MD2 compared to smooth Cayenne cultivar is less acidic, sweeter and is better appreciated by European consumers (Bartholomew, 2009; Syahrin, 2011). Its recent introduction to the international market was made from the Southern and Central American countries. This situation was seriously detrimental to Côte d'Ivoire, whose production fell by more than a quarter (1/4) with 46,258 tons in 2016 (FAO, 2018). In order to regain its market share, the country must adopt MD2 cultivation with a well-developed production technical itinerary (Ouattara, 2015). However, pineapple cultivation in Côte d'Ivoire suffers from a critical lack of planting material (suckers).

In pineapple cultivation, there are several methods of sucker production, the most common of which in Côte d'Ivoire is direct caring of stumps after fruit harvesting. It is very practical and requires little financial means. It is in this context that a study on the production of post-harvest suckers in rural environment in Bonoua, Southeastern Côte d'Ivoire, was carried out so as to select the cultural practices that can improve sucker production. This study aims at identifying planting beds and types of manure to be applied to the main crop likely to improve the production of MD2 pineapple suckers.

\section{Materials and methods}

\section{Study site}

The study took place on the Kakoukro Limite site located at $21 \mathrm{~km}$ from Bonoua in the administrative region of Sud-Comoé in Southeastern Côte d'Ivoire and the latitude is $5^{\circ} 21^{\prime} 46.2^{\prime \prime}$ North with a longitude of $3^{\circ} 26^{\prime} 03.5^{\prime \prime}$ West. The rainfall there is more than $1200 \mathrm{~mm}$ per year. The trials were set up on a fallow land, poor in mineral elements and whose granulometric composition is sandy-clay type with an acid pH (Ouattara, 2015).

\section{Plant material}

The variety of pineapple used was Extra Sweet or MD2. The study mainly focused on the suckers produced by pineapple stumps after fruit harvesting.

\section{Technical material}

Technical equipment included urea, mineral elements, a herbicide, a fungicide, a nematicide, a ridger, polyethylene film, scales, backpack sprayer and small agricultural equipment.

\section{Methods}

\section{Experimental design}

The experimental design adopted for the implementation was a split-plot with three blocks. The size of blocks was $32 \mathrm{~m} \times 10 \mathrm{~m}$ and that of plots (sub-blocks) was $10 \mathrm{~m} \times 10 \mathrm{~m}$. In this design, planting bed was the main factor and manure was the secondary one. The suckers were planted in staggered rows following double rows.

Planting beds designed to receive suckers that were used for the main crop included: the uncovered ridges (BSP), film-covered ridges (BAP) and flat soils (TP). Before laying the polyethylene cover, a herbicide (bromacile) was applied at a dose of 2 $\mathrm{kg}$.ha ${ }^{-1}$, on the ridges, including uncovered ones and flat soils (Fig. 1).

The types of manure used included: manures F1: Urea + Potassium $(\mathrm{K})$ + Trace elements (Boron + Zinc), F2: Urea + Potassium (K) + Nitrogen, Phosphorus and Potassium (NPK) compound / Magnesium Monoxide (MgO) + Trace elements (Boron + Zinc), F3: Urea + Potassium (K) and F4: Urea + Potassium (K) NPK / Nitrogen, Phosphorus and Potassium (NPK) compound / Magnesium Monoxide ( $\mathrm{MgO})$. The first fertilizer application was made one month after planting and this was spread out over 7 months. The initial supply was made in solid form (granulated) on the axil of first leaves and the others in liquid form (mist) on all the leaves. Manure types and total quantities of fertilizers received by each plant during the entire vegetative phase, as given in Table 1. 

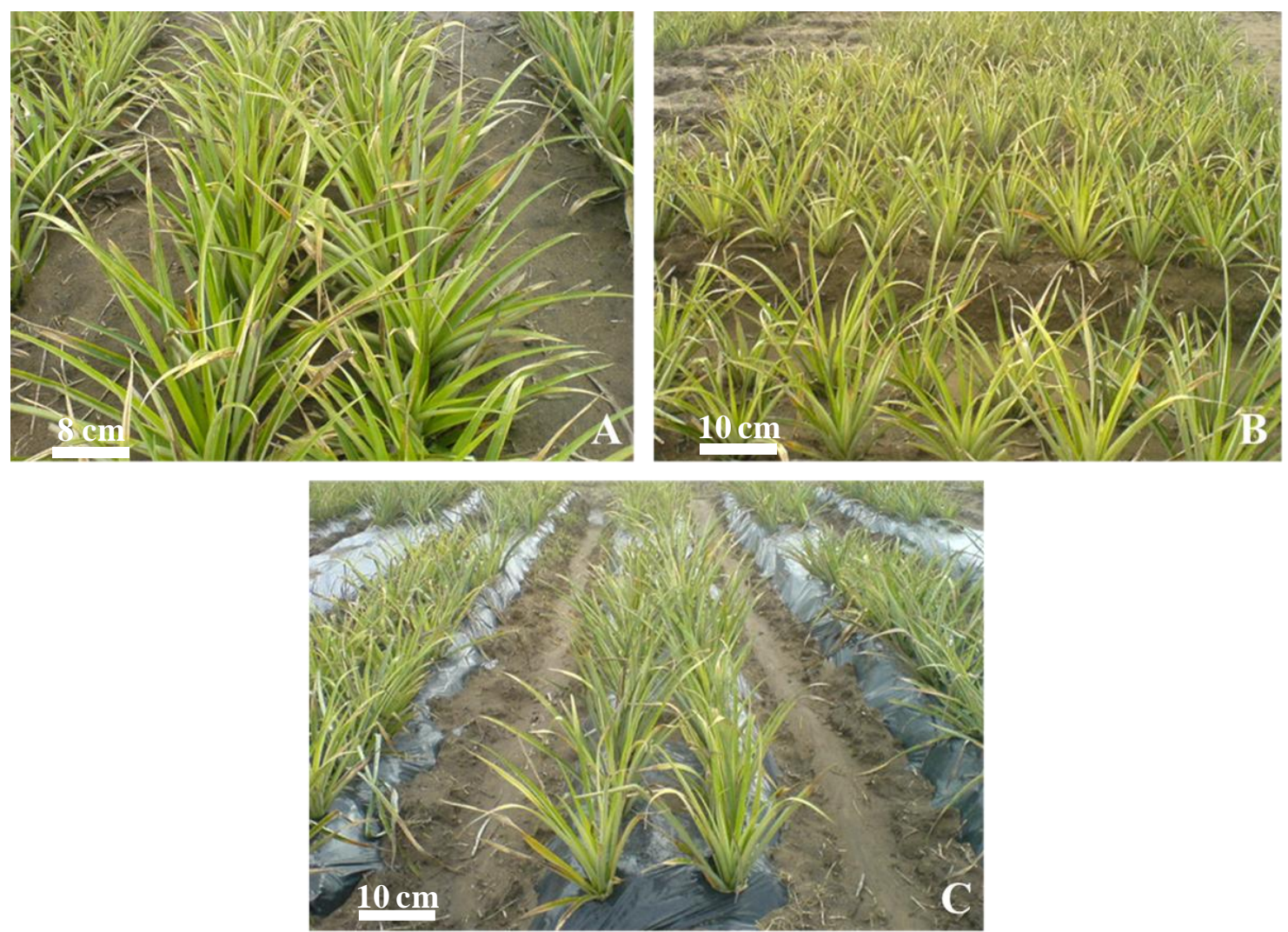

Fig. 1: MD2 pineapple sucker plantation on flat soil (A), bare ridges (B) and film-covered ridges (C).

Table 1. Manure types and total amount of fertilizer received per MD2 pineapple plant during the vegetative phase of crop cycle.

\begin{tabular}{|c|c|c|}
\hline Manures & Fertilizing elements & $\begin{array}{l}\text { Total quantities of } \\
\text { fertilizers per plant }\end{array}$ \\
\hline \multirow{2}{*}{ F1 } & Urea (46\% nitrogen) & $11 \mathrm{~g}$ \\
\hline & Potash [standard potassium sulfate: potassium oxide $\left(\mathrm{K}_{2} \mathrm{O}\right)$ 50\%; sulfur (S) $17 \%$ ] & $25 \mathrm{~g}$ \\
\hline \multirow{3}{*}{ F2 } & Urea (46\% nitrogen) & $11 \mathrm{~g}$ \\
\hline & Potash [standard potassium sulphate: potassium oxide $\left(\mathrm{K}_{2} \mathrm{O}\right) 50 \%$; sulfur $(\mathrm{S}) 17 \%$ ] & $25 \mathrm{~g}$ \\
\hline & $\begin{array}{l}\text { Trace elements: boron } 0.51 \mathrm{~g} / \mathrm{l} \text {; EDTA chelated copper } 0.25 \mathrm{~g} / \mathrm{l} \text {; EDTA chelated iron } \\
\text { o.16 g/l; molybdenum 0.05 g/l; zinc } 0.47 \mathrm{~g} / \mathrm{l} \text { of which EDTA chelated Zn } 0.0065 \\
\mathrm{~g} / \mathrm{l} \text {; EDTA chelated manganese } 0.51 \mathrm{~g} / \mathrm{l}\end{array}$ & $0.06 \mathrm{ml}(4 \mathrm{l} / \mathrm{ha})$ \\
\hline \multirow{3}{*}{ F3 } & Urea (46\% nitrogen) & 8 to $10 \mathrm{~g}$ \\
\hline & Potash [standard potassium sulphate: potassium oxide $\left(\mathrm{K}_{2} \mathrm{O}\right) 50 \%$; sulfur $(\mathrm{S}) 17 \%$ ] & 17 to $22 \mathrm{~g}$ \\
\hline & $\begin{array}{l}\text { Complete fertilizer: nitrogen }(\mathrm{N}) 11 \% \text {; phosphate }\left(\mathrm{P}_{2} \mathrm{O}_{3}\right) 5 \% \text {; potassium oxide }\left(\mathrm{K}_{2} \mathrm{O}\right) \\
27 \% \text {; sulfur }(\mathrm{S}) 15 \% ; 5 \% \text { magnesium oxide }(\mathrm{MgO})\end{array}$ & 6 to $15 \mathrm{~g}$ (200 to $400 \mathrm{~kg} / \mathrm{ha})$ \\
\hline \multirow{4}{*}{$\mathrm{F} 4$} & Urea (46\% nitrogen) & 8 to $10 \mathrm{~g}$ \\
\hline & Potash [standard potassium sulphate: potassium oxide $\left(\mathrm{K}_{2} \mathrm{O}\right)$ 50\%; sulfur $(\mathrm{S}) 17 \%$ ] & 17 to $22 \mathrm{~g}$ \\
\hline & $\begin{array}{l}\text { Complete fertilizer: nitrogen }(\mathrm{N}) 11 \% \text {; phosphate }\left(\mathrm{P}_{2} \mathrm{O}_{3}\right) 5 \% \text {; potassium oxide }\left(\mathrm{K}_{2} \mathrm{O}\right) \\
27 \% \text {; sulfur }(\mathrm{S}) 15 \% ; 5 \% \text { magnesium oxide }(\mathrm{MgO})\end{array}$ & 6 to $15 \mathrm{~g}$ (200 to $400 \mathrm{~kg} / \mathrm{ha})$ \\
\hline & $\begin{array}{l}\text { Trace elements: boron } 0.51 \mathrm{~g} / \mathrm{l} \text {; EDTA chelated copper } 0.25 \mathrm{~g} / \mathrm{l} \text {; EDTA chelated iron } \\
\text { o.16 g/l; molybdenum 0.05 g/l; zinc 0.47 g/l of which EDTA chelated Zn } 0.0065 \\
\mathrm{~g} / \mathrm{l} \text {; EDTA chelated manganese } 0.51 \mathrm{~g} / \mathrm{l}\end{array}$ & $0.06 \mathrm{ml}(4 \mathrm{l} / \mathrm{ha})$ \\
\hline
\end{tabular}




\section{Plantation caring during sucker production phase after fruit harvesting}

Weeding was done both manually and with chemicals using a sprayer. Indeed, weeding between the planting rows was carried out using a hoe, while that of the paths between sub-block and block was carried out by spraying a herbicide whose active ingredient is Bromacil ( $\left.2 \mathrm{~kg} \mathrm{ha}^{-1}\right)$. Two fertilizer applications were made during sucker production cycle. They took place in the first and third months after fruit harvesting. The fertilizer used was urea (46\% nitrogen). During the first month, urea in solid form was deposited at the base of each stump at a rate of 4 to $5 \mathrm{~g}$. in the third month, $8 \mathrm{~kg}$ of urea was dissolved in 200 liters of water. By means of a sprayer, this quantity was spread over the leaf surface of suckers in production in order to allow their quick development.

\section{Assessment of planting bed and fertilizer effects on plant vegetative growth}

It should be noted that all the measurements carried out (measurement of the size, the total number of leaves, and monthly-generated leaves) were made from the third to the sixth month after fruit harvesting.

\section{Sucker types and count}

For each planting bed and for each type of manure, all the suckers (aerial, slips, happa) carried by each stump were counted in the fourth month after fruit harvesting.

\section{Sucker height measurement}

For measuring the height of suckers, a tape measure fixed along a stick was used. The method consisted in placing the zero point of the measuring tape at the base of the sucker, that is to say the area of insertion of the sucker on the stump, and then gathering the entire sucker leaves along the measuring tape and noting the measurement of the longest leaf. This measurement constituted the height of suckers.

\section{Determination of the total number of leaves}

The count involved five plants per treatment. The count was made from the old leaves still green to the last visible leaf in the core of the rosette.

\section{Determination of the monthly leaf- generation frequency}

Using an indelible marker, the last visible leaf in the core of the leaf bouquet was marked one month before the number of generated leaves was counted. New generated leaves were the ones that came out after the marked leaf.

\section{Determination of sucker weight}

A Roberval scales was used to determine sucker weight. After tare weight, the sucker was placed on the scale and the displayed mass was noted in grams.

\section{Statistical analysis of data}

The data collected were subjected to an analysis of variance (ANOVA) with STATISTICA 7.1 software. In the event of significant differences, the averages were compared according to the Newman-keuls test at $5 \%$ threshold.

\section{Results}

\section{Influence of planting bed on the weight of suckers produced}

Fig. 2 shows the influence of planting beds on the weight of suckers produced four (6) six after fruit harvesting. Film-covered ridges produced $475 \mathrm{~g}$ suckers. Uncovered ones were $450 \mathrm{~g}$, and flat soil ones were $367 \mathrm{~g}$. The differences noted between the fresh mass of plants for planting beds were significant $(\mathrm{P}=0.000)$ at $5 \%$ threshold of the Newman-Keuls test.

\section{Influence of planting beds on the total number of leaves produced}

The total number of leaves was statistically identical on BAP and BSP planting beds with values higher than 31 leaves. As for suckers in production on TP they had the lowest number of leaves (29) compared to BAP and BSP planting beds (Fig. 3). The difference observed between the number of leaves depending on planting beds was significant with $\mathrm{P}=0.000$ at $5 \%$ threshold of the Newman-Keuls test. 


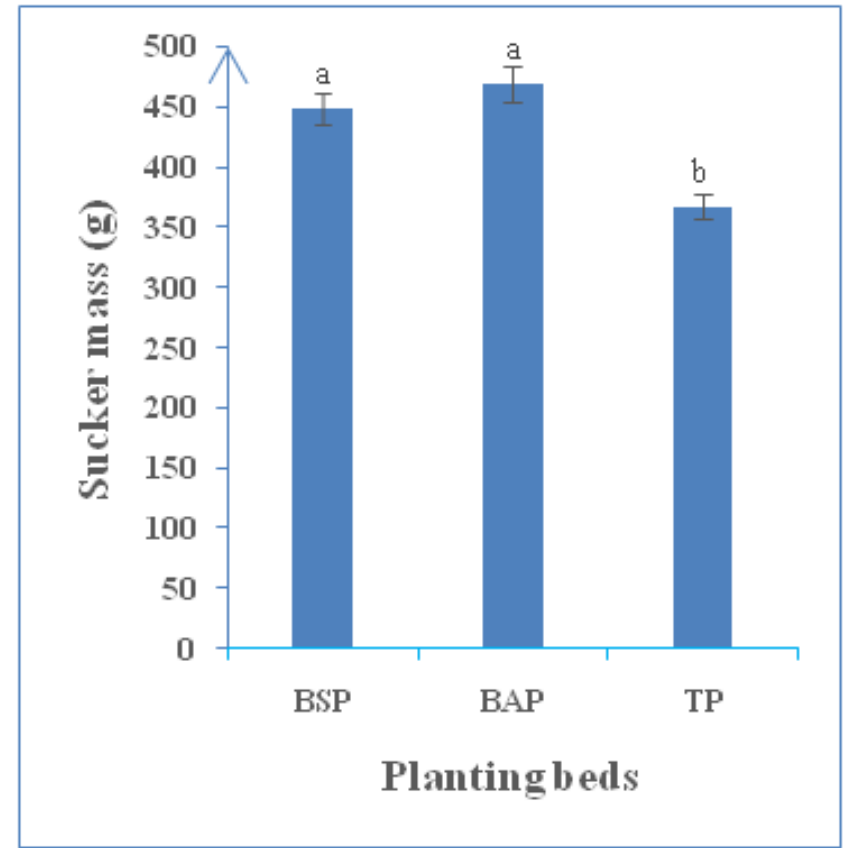

Fig. 2: Average sucker mass according to planting beds BAP, BSP and TP. BAP: film-covered ridges; BSP: filmuncovered ridges; TP: flat soil. The averages assigned with different letters on the histograms are significantly different at $5 \%$ threshold (Newman-Keuls test).

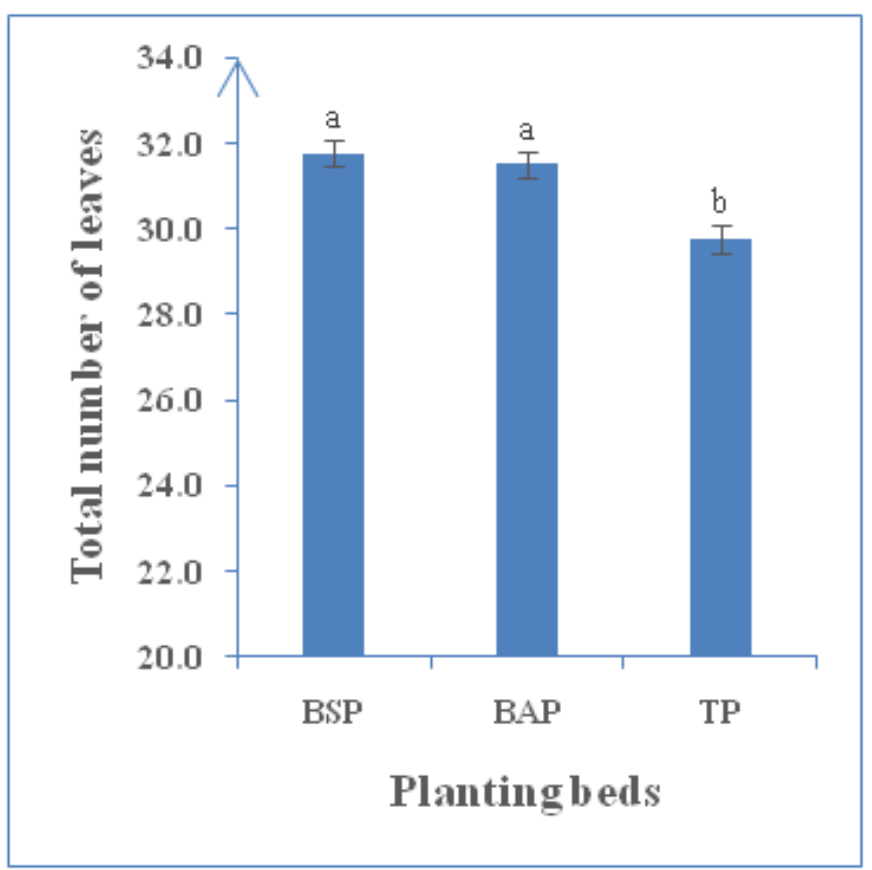

Fig. 3: Total number of leaves depending on planting beds BAP, BSP and TP. BAP: film-covered ridges; BSP: film- uncovered ridges; TP: flat soil. The averages assigned with different letters on the histograms are significantly different at $5 \%$ threshold (Newman-Keuls test).

\section{Influence of planting beds on the monthly leaf-generation frequency}

The number of leaves generated monthly by suckers was higher on BAP and BSP beds (3.8) than on TP (3.6). A significant difference $(\mathrm{P}=$ 0.002) was noted between the different planting beds (Fig. 4).

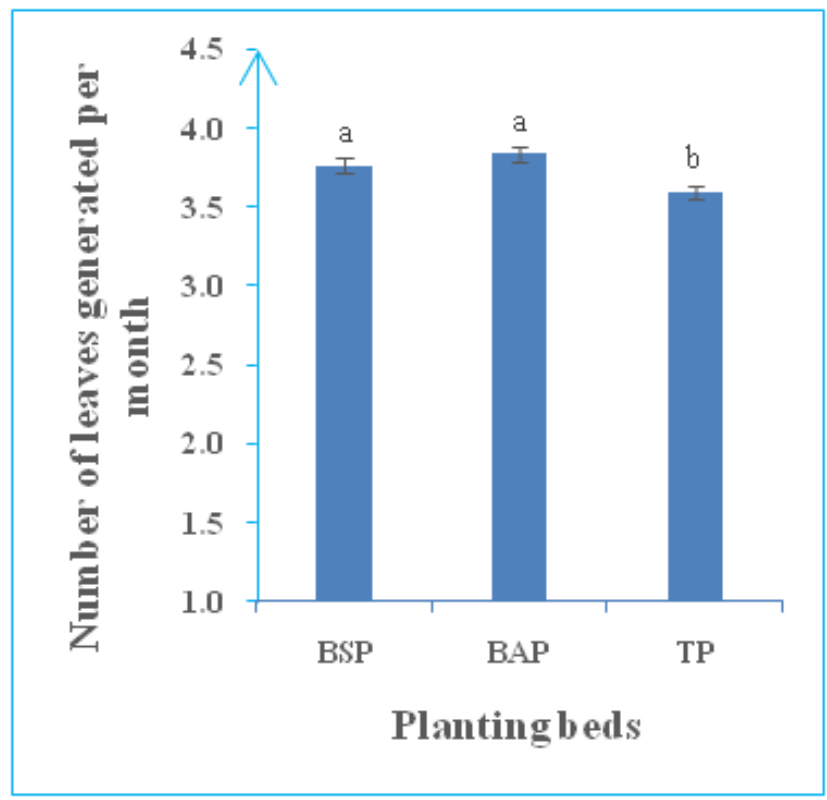

Fig. 4: Number of leaves generated per month depending on the planting beds BAP, BSP and TP. BAP: film-covered ridges; BSP: film-uncovered ridges; TP: flat soil. The averages assigned with different letters on the histograms are significantly different at 5\% threshold (Newman-Keuls test).

\section{Influence of planting beds on the quantity of suckers produced four months after fruit harvesting}

Four months after fruit harvesting, the production of aerial suckers was 1.32 sucker/stump on BAP, 1.27 suckers per BSP stump and 1.13 suckers per TP stump. Statistical analyses showed a significant difference $(\mathrm{P}=0.000)$ at $5 \%$ threshold with two homogeneous groups. Aerial suckers were more produced than ground suckers regardless of the planting bed (Table 2).

\section{Influence of planting beds on sucker types produced per stump}

The results recorded in Fig. 5 show that aerial suckers are the types of suckers most produced by 
a pineapple stump. For BAP, BSP, and TP planting beds, the proportion of suckers was 94, 95 and 97\%, respectively. The proportion of slips for BAP, BSP, and TP was 1.90, 2.0 and 1.10\%, respectively.
As for happa production, the proportions 1.50; 0.70 and $0.10 \%$ respectively for BAP, BSP, and TP was noted. Similarly for BAP, BSP, and TP, the proportions of ground suckers were respectively $2.30,1.80$ and $1.60 \%$.

Table 2. Production of suckers 6 months after fruit harvesting depending on planting bedBAP, BSP and TP.

\begin{tabular}{|c|c|c|c|c|c|}
\hline \multirow[b]{2}{*}{$\begin{array}{l}\text { Planting } \\
\text { bed }\end{array}$} & \multicolumn{2}{|c|}{ Types of suckers } & \multirow[b]{2}{*}{$\begin{array}{l}\text { Total aerial and } \\
\text { ground suckers }\end{array}$} & \multirow[b]{2}{*}{$\begin{array}{l}\text { No. of } \\
\text { stumps }\end{array}$} & \multirow[b]{2}{*}{$\begin{array}{l}\text { No. of } \\
\text { suckers/stumps }\end{array}$} \\
\hline & $\begin{array}{l}\text { No. of aerial } \\
\text { suckers }\end{array}$ & $\begin{array}{l}\text { No. of ground } \\
\text { suckers }\end{array}$ & & & \\
\hline$\overline{\text { BAP }}$ & 1711 & 35 & 1746 & 1319 & $1.32 \pm 1.12 \mathrm{a}$ \\
\hline BSP & 1655 & 28 & 1683 & 1319 & $1.27 \pm 0.75 \mathrm{a}$ \\
\hline $\mathrm{TP}$ & 1477 & 20 & 1497 & 1319 & $1.13 \pm 0.8 \mathrm{~b}$ \\
\hline Total & 4843 & 83 & 4506 & 3956 & 1.24 \\
\hline
\end{tabular}

BAP: film-covered ridges; BSP: film-uncovered ridges; TP: flat soil. The averages assigned with different letters on the table are significantly different at $5 \%$ threshold (Newman-Keuls test), average \pm Ecart-type.
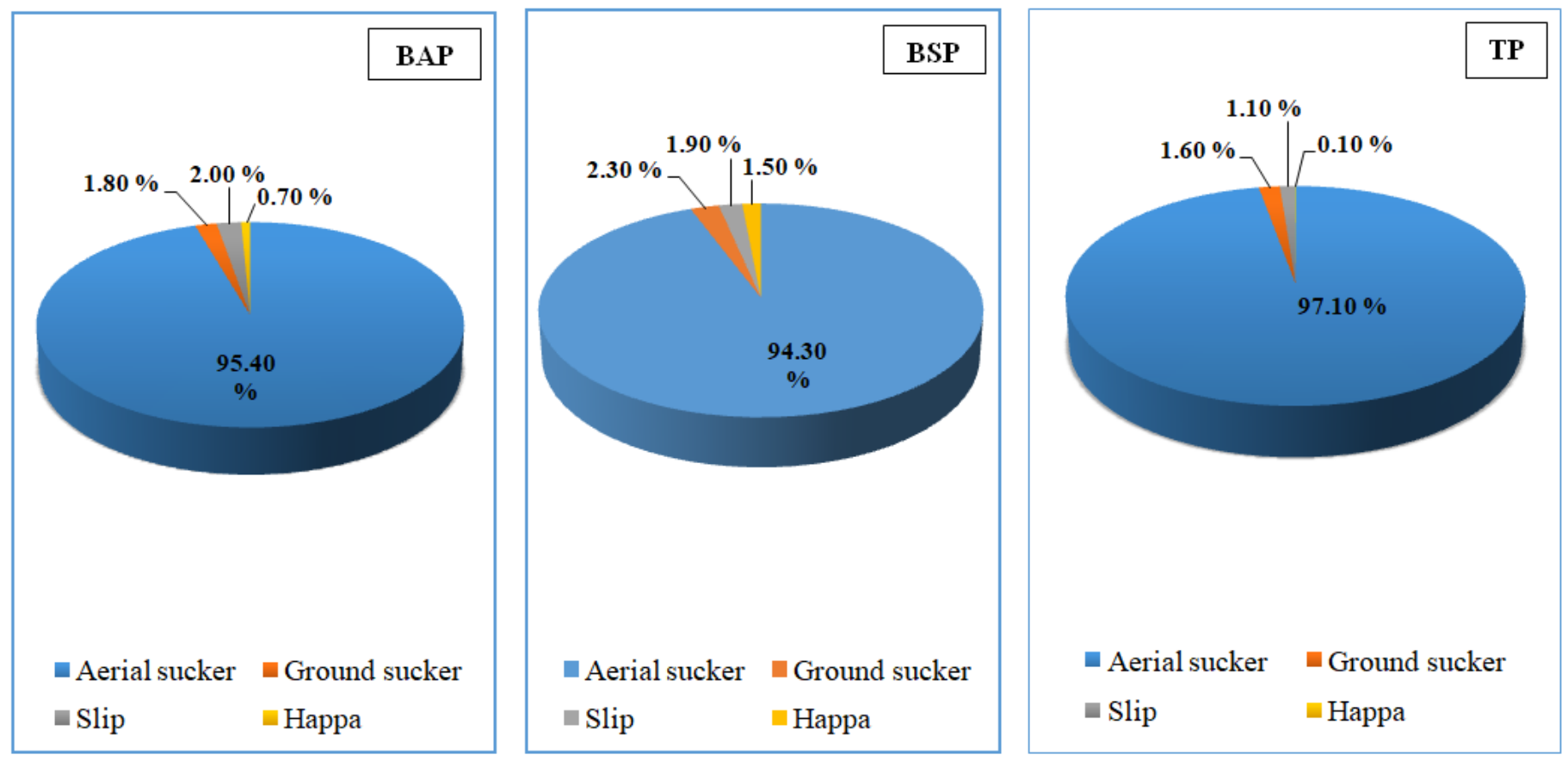

Fig. 5: Proportion of the different types of suckers obtained depending on planting beds BAP, BSP and TP after fruit harvesting; BAP: film-covered ridges; BSP: film-uncovered ridges; TP: flat soil.

\section{Influence of fertilizer types on the weight of sucker produced}

Six months after fruit harvesting, all of the suckers had masses higher than $400 \mathrm{~g}$ regardless of manure type (Fig. 6). The statistical analysis did not detect any significant difference $(\mathrm{P}=0.415)$ at $5 \%$ threshold (Newman-Keuls test) between the masses of suckers produced on the different types of manure.

\section{Influence of fertilizer type on the total number of leaves}

The total number of leaves varied from 29.96 to 32 leaves depending on the type of manure (Fig. 7). Statistical differences $(\mathrm{P}=0.001)$ were observed between treatments. The highest number of leaves was noted with F2 manure (32 leaves) and the lowest with F1 manure (29.96 leaves) for an overall average of 31 leaves. 


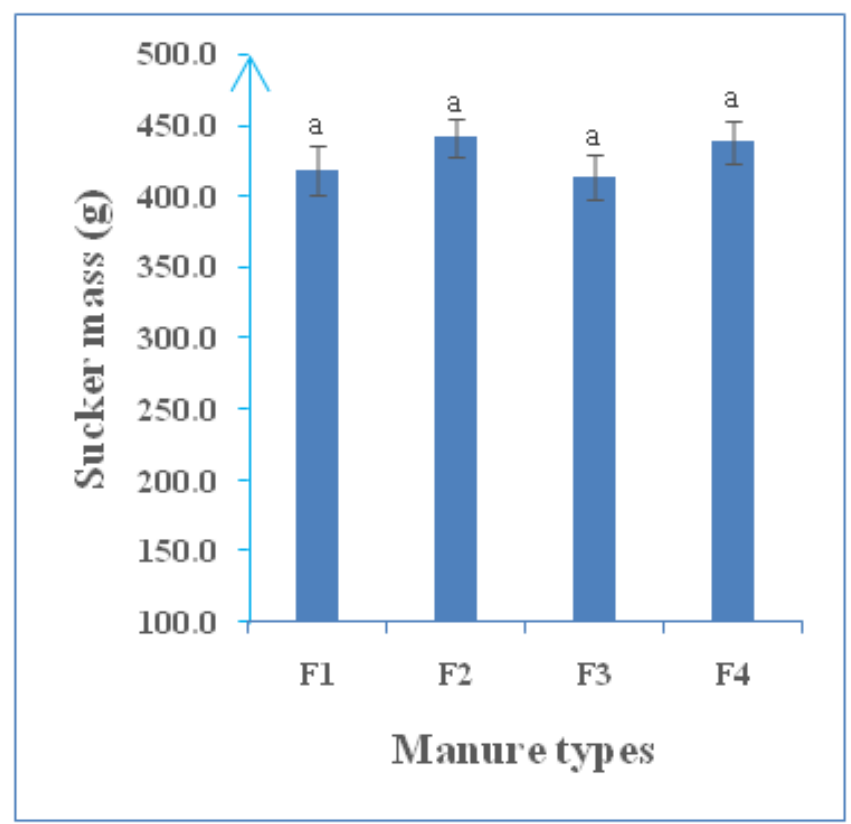

Fig. 6: Average sucker mass depending on manure F1, F2, F3 and F4. F1: urea $+\mathrm{K}+$ trace elements; F2: urea $+\mathrm{K}+\mathrm{NPK} / \mathrm{MgO}+$ trace elements; F3: urea + K; F4: urea $+\mathrm{K}+\mathrm{NPK} / \mathrm{MgO}$. The averages assigned with the same letter on the histograms are not significantly different at $5 \%$ threshold (Newman-Keuls test).

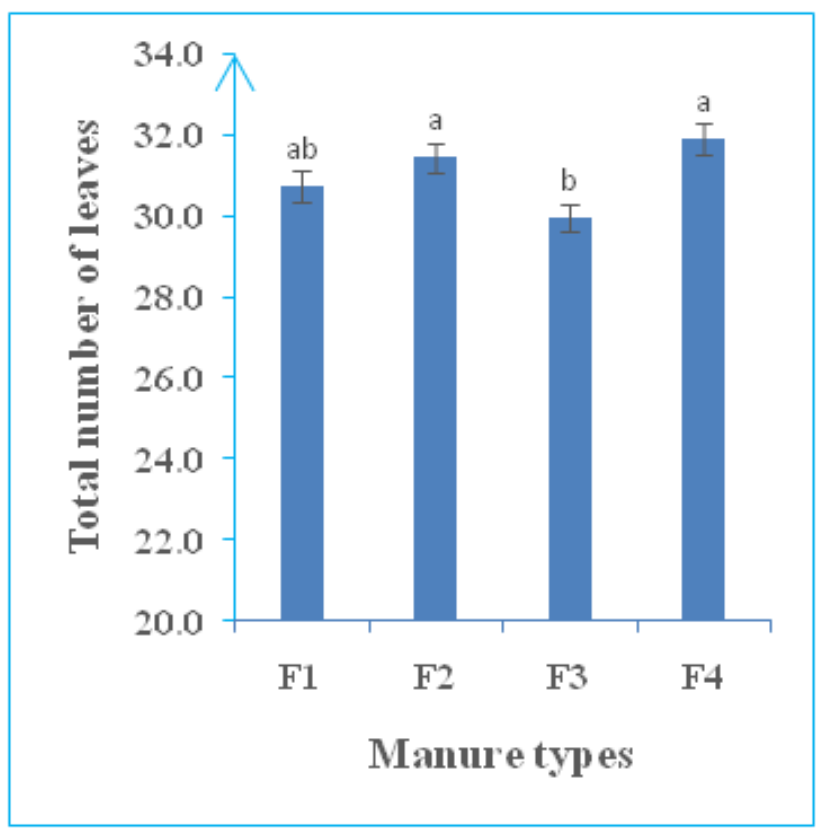

Fig. 7: Total number of leaves depending on manure F1, F2, F3 and F4. F1: urea $+\mathrm{K}+$ trace elements; F2: urea $+\mathrm{K}+\mathrm{NPK} / \mathrm{MgO}+$ trace elements; F3: urea + K; F4: urea + K + NPK / MgO. The averages assigned with the same letter on the histograms are not significantly different at $5 \%$ threshold (Newman-Keuls test).

\section{Influence of fertilizer typeon the monthly leaf-generation frequency}

Leaf generation was statistically identical $(\mathrm{P}=$ o.835) at $5 \%$ threshold for all suckers regardless of the type of manure used (Fig. 8). It varied between $3.6\left(\mathrm{~F}_{1}\right)$ and $3.75\left(\mathrm{~F}_{3}\right)$ leaves per month.

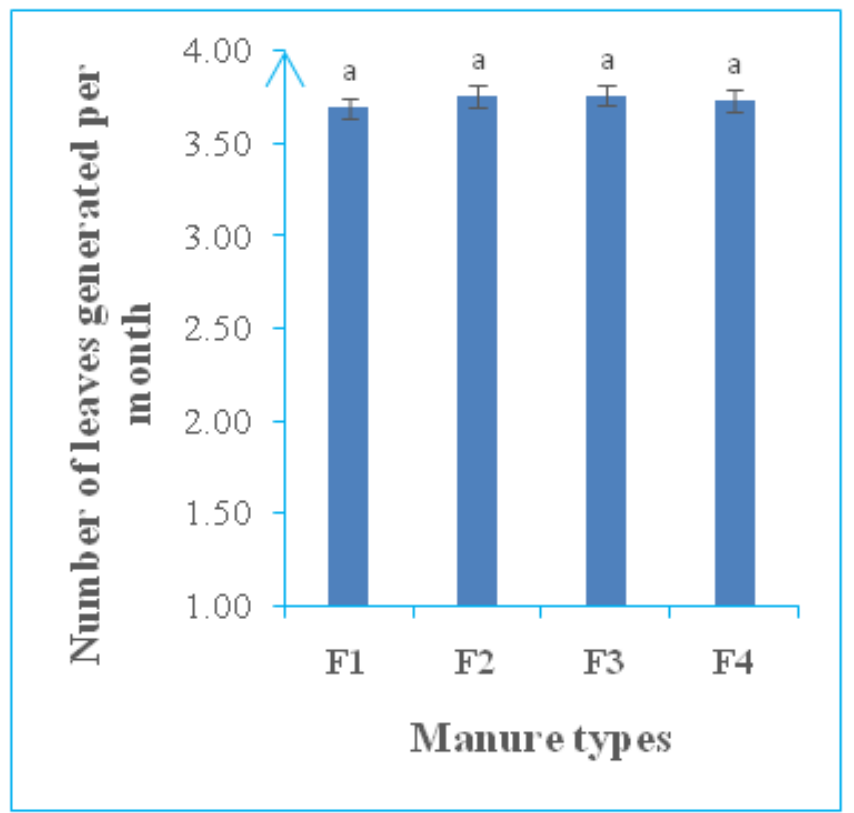

Fig. 8: Total number of leaves depending on manure F1, F2, F3 and F4. F1: urea + K + trace elements; F2: urea + K + NPK / MgO + trace elements; F3: urea + K; F4: urea + K + NPK / MgO. The averages assigned with the same letter on the histograms are not significantly different at $5 \%$ threshold (Newman-Keuls test).

\section{Effects of manure types on the quantity of suckers produced per stump four months after fruit harvesting}

Six months after the fruit harvesting (Table 3), the production of aerial suckers was 1.27 and 1.21 sucker per stump with $\mathrm{F}_{4}$ and $\mathrm{F}_{3}$ manure. With F1 and $\mathrm{F} 2$, production was identical (1.25 sucker per stump). Statistical analyses showed that there was no significant difference on the action of manures on sucker production per stump ( $\mathrm{P}=0.0815$ at $5 \%$ threshold on the Newman-Keuls test.

\section{Sucker types produced per stump}

Analysis of Fig. 9 has shown that whatever the type of manure used, aerial suckers were the ones that were most produced by stumps. Thus 94.33 ; 95.96; 95.54 and $96.24 \%$ of suckers produced were aerial, 
with manures F1, F2, F3 and F4, respectively. The proportion of slips for $\mathrm{F} 1, \mathrm{~F} 2, \mathrm{~F}_{3}$ and $\mathrm{F} 4$ was 2.17; $1.47 ; 1.74$ and $1.54 \%$, respectively. As for happa production, we noted the proportions 0.75 ; 0.86 ;
0.89 and $0.77 \%$, for $\mathrm{F} 1, \mathrm{~F} 2, \mathrm{~F}_{3}$ and $\mathrm{F} 4$, respectively. Similarly for F1, F2, F3 and F4 the proportions of ground suckers were $2.75 ; 1.71 ; 1.83$ and $1.46 \%$, respectively.

Table 3. Production of suckers 6 months after fruit harvesting depending on manureF1, F2, F3 and F4.

\begin{tabular}{llllll}
\hline $\begin{array}{l}\text { Types of } \\
\text { manure }\end{array}$ & $\begin{array}{l}\text { Types of suckers } \\
\text { No. of aerial } \\
\text { Suckers }\end{array}$ & $\begin{array}{l}\text { No. of ground } \\
\text { suckers }\end{array}$ & $\begin{array}{l}\text { Total aerial and } \\
\text { ground suckers }\end{array}$ & No. of stumps & $\begin{array}{l}\text { No. of } \\
\text { suckers/stumps }\end{array}$ \\
\hline F1 & 1204 & 29 & 1233 & 989 & $1.25 \pm 0.75 \mathrm{a}$ \\
F2 & 1230 & 22 & 1252 & 1001 & $1.25 \pm 0.75 \mathrm{a}$ \\
F3 & 1174 & 19 & 1193 & 987 & $1.21 \pm 0.75 \mathrm{a}$ \\
F4 & 1235 & 13 & 1248 & 979 & $1.27 \pm 1.25 \mathrm{a}$ \\
Total & 4843 & 83 & 4926 & 3956 & 1.25 \\
\hline
\end{tabular}

F1: urea + K + trace elements ; F2: urea + K + NPK / MgO + trace elements ; F3: urea + K ; F4: urea + K + NPK / $\mathrm{MgO}$. The averages assigned with different letters on the table are significantly different at $5 \%$ threshold (NewmanKeuls test), average \pm Ecart-type.

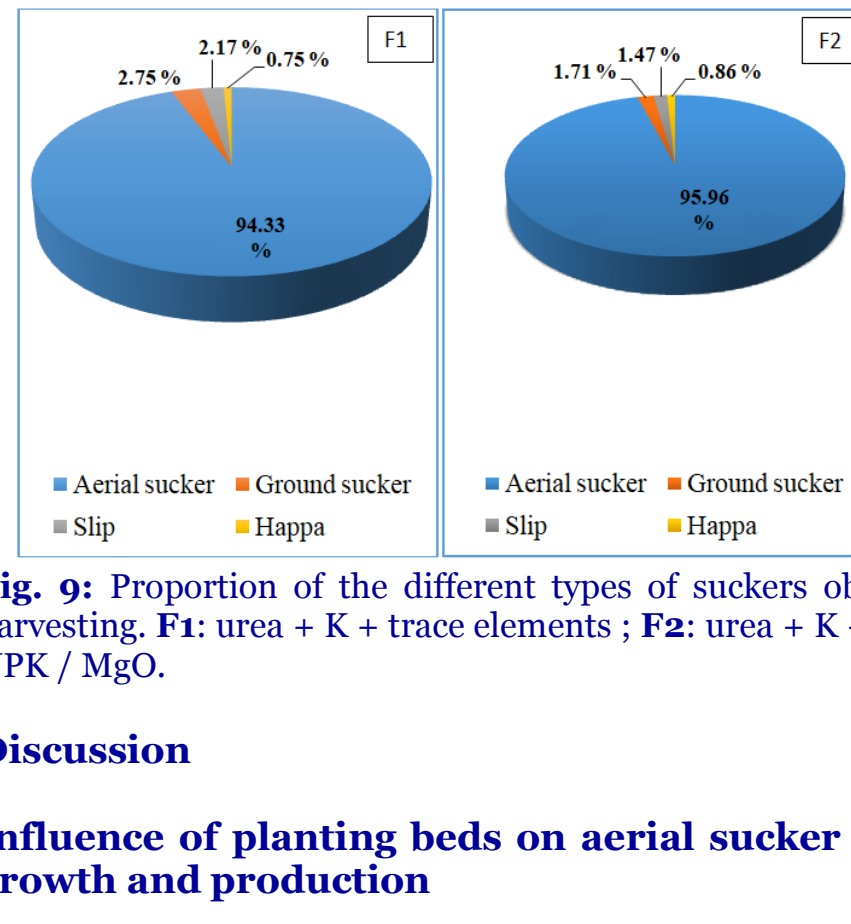

The results obtained show that planting beds significantly influence the ability of pineapple stump to produce quality and quantity suckers. These results are consistent with those of Kouelo et al. (2012) who showed that tillage significantly influences Macrotyloma geocarpum productivity.

The significant difference observed between ridged planting beds (BAP and BSP) and unridged planting beds (Flat soil) both in terms of growth and in terms of production, is due to the fact that regarding ridges, we do have a well ventilated and NPK/MgO.

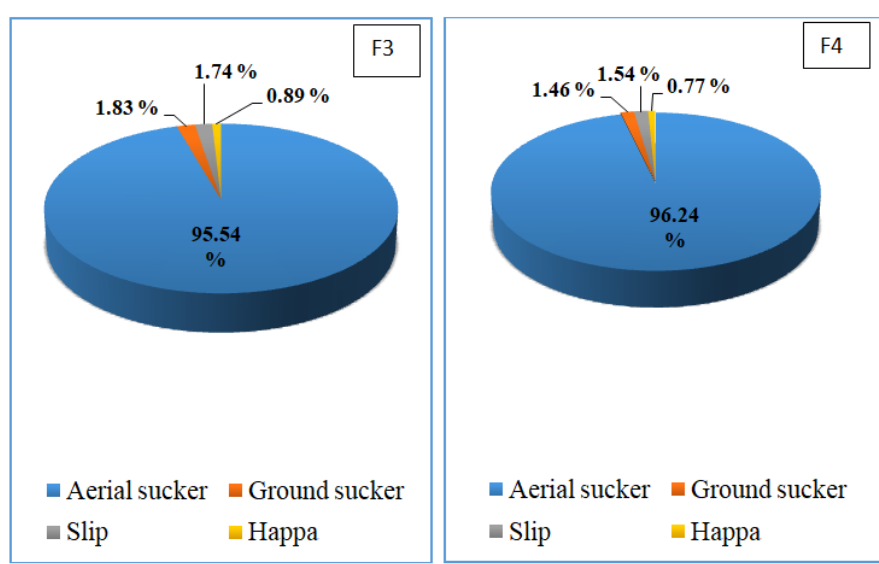

Aerial sucker $\quad$ Ground sucker
$=$ Slip
$=$ Happa

Fig. 9: Proportion of the different types of suckers obtained depending on manure F1, F2, F3 and F4 after fruit harvesting. F1: urea + K + trace elements ; F2: urea + K + NPK / MgO + trace elements ; F3: urea + K ; F4: urea + K +

\section{Influence of planting beds on aerial sucker}

N. M. Kanga et al. (2020) / Effects of planting bed and mineral fertilization on the production and growth of Extra Sweet pineapple (Ananas comosus L.) aerial suckers in the locality of Bonoua, a town in south eastern Côte d'Ivoire non-firm soil. This therefore allows the plants to have good growth because root aeration facilitates water and mineral nutrition of the plant. It should also be noted that the polyethylene film makes it possible to preserve soil moisture, reduce grass cover; which limits the phenomenon of competition. According to Py et al. (1984), when the soil is protected from compaction due to rain by polyethylene cover, the constant moisture allows more active and regular growth of the pineapple plant. The flat soil is much firmer than the others and is also less ventilated. However, it has been found that after fruit harvesting (which means that the apical dominance of the plant is removed), pineapple stumps have the ability to produce suckers. These results are similar to those obtained by Kaplan (1976) and Py (1979) who 
proved that apex decapitation during pineapple plant vegetative growth phase also allowed the development and growth of axillary buds. It was found that four months after fruit harvesting, the stumps were only able to produce an average of 1.3 sucker per foot. These results are contrary to those of Kanga, (2014), Munoz and Vargas (1996) and Perez (1994). Indeed, Kanga has shown that by the PIF technique (plants derived from stem fragments), young pineapple stumps made it possible to obtain on average around five suckers in three months. As for Munoz and Perez, they have shown that in banana, in situ techniques such as "folding the pseudo-stem" and "decapitations" allowed to obtain 4 to 8 suckers per foot on average.

\section{Influence of manure types on aerial sucker growth and production}

According to the results, manure types did not significantly influence aerial sucker growth and production after fruit harvesting. This lack of influence is due to the fact that pineapple, during its vegetative cycle needs urea and potash for its development (Kobenan et al., 2005). All four types of manure contained urea and potash. Nitrogen nutrition therefore determines the growth of pineapple plants as a priority (Py et al., 1984) and potassium acts favorably on the growth of the stem (Sideris and Young, 1945). The other elements such as phosphorus, magnesium and trace elements have a weaker action on pineapple plant growth and yield (Py et al., 1984). These results are in accordance with those obtained by Anonymous (1984) according to which trace elements, Magnesium and phosphorus do not influence pineapple plant growth and development but fruit quality.

\section{Conclusion}

Pineapple is a plant that produces suckers after fruit harvesting. The results obtained show that planting beds influence aerial sucker production and growth after fruit harvesting. Manure types did not differently influence sucker production and growth. It should therefore be noted that all the manures tested are ultimately valid for sucker production and growth. It is preferable for pineapple producers who wish to have good quality and sufficient suckers in this area of Côte d'Ivoire to opt for pineapple cultivation either on filmcovered ridge or uncovered ridge. As for the choice of manure, one of the four used here can be recommended.

\section{Conflict of interest statement}

Authors declare that they have no conflict of interest.

\section{Acknowledgement}

We sincerely thank the Interprofessional Fund for Research and the Agricultural Council (FIRCA) for funding this research work.

\section{References}

Anonymous, 2015. https://goutimot.com/ agriculture/productions/cultures/ananas-decote-d-ivoire, visité le o3 septembre 2019.

Anonymous, 1984. La culture de l'ananas d'exportation en Côte d'Ivoire. Manuel du planteur. Institue de recherche de fruit et d'agrume (IRFA). Les nouvelles éditions africaines. 112p.

Bartholomew, D. P., 2009. MD2 Pineapple transforms the world's pineapple fresh fruit export industry. Newsletter of the Pineapple Working Group, International Society for Horticultural Science. 16, 2-5.

Charrier, A., Michel, J., Hamon, S., Dominique, N., 1997. L'amélioration des plantes tropicales. 632p.

Collins, J.L. 1960. The pineapple: botany, utilisation, cultivation. Londres, RoyaumeUni, Leonard Hill, 294p.

FAO, 2018. FAOSTAT. Url: http://faostat3. fao.org/Août 2018. Consulté le 30 Août 2018.

Kanga, M., 2014. optimisation de la production de semences à partir de souches et de rejets: cas $\mathrm{du}$ bananier (Musa spp.) et de l'ananas (Ananas comosus L.), mémoire master de l'Université Félix Houphouët Boigny, Abidjan, Côte d'Ivoire, 53p.

Kaplan, J., 1976. La multiplication de l'ananas à la pépinière de Singher. Réunion. Annuelle IRFA, doc. Interne, $\mathrm{n}^{\circ} 47$.

Kobenan, K., Assienan, A. B., Yao, N.T., Gnonhouri, G.P., Kouassi, K.S., 2005. Bien cultiver l'ananas en Côte d'Ivoire. Direction des programmes de recherche et de l'appui 
au développement - Direction des systèmes d'information. CNRA (Centre National de Recherche Agronomique). 4p.

Kouelo, A.F., Badou, A., Houngnandan, P., Francisco, M., Michée, F., Gnimassoun, C. J.B., Sochime, D.J., 2012. Impact du travail du sol et de la fertilisation minérale du sol sur la productivité de Macrotyloma geocarpum J. Appl. Biosci. 51, 3625-3632.

Mangara, A., 2010. Les adventices en culture d'ananas: Ananas comosus (L.) Merr. (Bromeliaceae), dans les localités d'Anguédédou, de Bounoua et de N'douci, en basse Côte d'Ivoire : inventaire et essai de lutte. Thèse de Doctorat de l'Université de CocodyAbidjan, UFR Biosciences. 208p.

Munoz, C., Vargas, H., 1996. Evaluación de la metodología de "multiplicación rápida" en plátano (Musa AAB), Corbana (Costa Rica) 21 (46), 141-144.

OCAB (Organisation Centrale des producteurs exportateurs d'Ananas et de Bananes), 2000. Le commerce, l'environnement et le développe ment durable en Afrique de l'ouest et du centre dans une perspective sectorielle: cas de la production et de l'exportation de l'ananas, de la banane et de la mangue de Côte d'Ivoire, 14p.
Ouattara, G., 2015. Evaluation agrophysiologique d'itinéraires techniques élaborés pour une production rentable de Ananas comosus (L.) Merr. var. (Bromeliaceae) en Côte d'Ivoire, Thèse de Doctorat de l'Université Félix Houphouët Boigny, 198p.

Paqui, T., 2007. Dossier Ananas. Fruitrop. 144, 519.

Perez, L., 1994. Comparación de varios métodos de propagación en banano, in: Contreras, M.M.A., Guzmán Chaves, J. A., Carrasco L.R. (Eds.), Mem. X reun., ACORBAT 91, ACORBAT, San José, Costa Rica, pp.15-25.

Py, C., 1979. Production accélérée de matériel végétal de plantation. Fruits. 34(2), 107-116.

Py, C., Lacoeuilhe, J. J., Teisson, C., 1984. L'ananas: sa culture, ses produits. Collection: Techniques agricoles et productions tropicales. G. P. Maisonneuve et Larose (Eds.). Agence de Coopération Culturelle et Technique. 564p.

Sideris, C. P., Young, H. Y., 1945. Effects of different amounts of potassium on growth and ash constituents of Ananas comosus (L.) Merr. Plant Physiol. 20, 609-630.

Syahrin, S., 2011. Consumer preferences towards pineapple cultivars in Malaysia. Acta Hort. 902, 595-599.

\section{How to cite this article:}

Kanga, N. M., Cherif, M., Sanogo, S., Tuo, S., Yao, K. J. E., Kouassi, N’dri P., Konan K. S., Bomisso, E. L., Camara, B., Sorho, F., Dick, A. E., Koné, D., 2020. Effects of planting bed and mineral fertilization on the production and growth of Extra Sweet pineapple (Ananas comosus L.) aerial suckers in the locality of Bonoua, a town in south eastern Côte d'Ivoire. Int. J. Curr. Res. Biosci. Plant Biol. 7(1), 23-32.

doi: https://doi.org/10.20546/ijcrbp.2020.701.003 